\title{
Editorial
}

Intervirology

\section{Giant Viruses from Amoeba in a Post-Darwinist Viral World}

\author{
Didier Raoult
}

URMITE, UMR 6236, IRD UMR 198, Faculté de Médecine, Université de la Méditerranée, Marseille, France

\begin{abstract}
Key Words
Giant virus $\cdot$ Marseillevirus $\cdot$ Mimivirus $\cdot$ Rhizome $\cdot$

Virophage $\cdot$ Virus definition
\end{abstract}

The viruses, the virological field and their definitions were influenced deeply by initial studies of viruses as disease-causing agents that were filterable (passing through $0.2-\mu \mathrm{m}$ filters) and found in humans, animals and plants [1]. It is for this reason that viruses of bacteria, which were discovered later, were named bacteriophages rather than viruses. This double definition of viruses (virulent and filterable) implies that viruses were considered, and are still considered by most biologists today, as being of small size. Thus, most studies of viral metagenomics [2] base their selection of viruses on filtered samples, which enables them to find only viruses of small size. However, this a priori notion of viruses creates a circular definition. In addition, the focus on specialized viruses as pathogens has created a very restricted niche for the study of viruses and biased observations of them. Hyper-specialization toward infection of a very specific host promotes reductive evolution of intracellular bacteria and viruses $[3,4]$. In fact, allopatric specialization (genetic isolation) causes a regular reduction in the genome size of organisms because of their inability to acquire additional genes from neighbors. Under these conditions, the balance between gene gain and gene loss tends toward gene loss and genome reduction.

\section{KARGER \\ Fax +4161306 1234 \\ E-Mail karger@karger.ch}

www.karger.com
(C) 2010 S. Karger AG, Basel

0300-5526/10/0535-0251\$26.00/0

Accessible online at: www.karger.com/int
Amoebae are phagocytic protists that allow intracellular bacteria, fungi and viruses to live sympatrically (in the same niche) and thus make it possible and easy for them to exchange genes. They constitute a remarkable tool to study pathogenic bacteria. The use of these amoebae has been critical in isolating Legionella pneumophila strains and studying their pathogenicity [5]. Using this tool, T. Rowbotham began a collection of microorganisms that he thought were associated with pneumonias and considered these as 'Legionella like amoebal pathogens' [6]. For many years, our team has studied amoebae $[7,8]$ in order to evaluate whether or not they can be used as a reservoir, or Trojan horse, for intracellular bacteria. The study of Rowbotham's collection enabled us, along with La Scola et al. [9], to identify Mimivirus for the first time; this virus resisted our attempts at identification with universal bacterial primers. Starting with this work, we obtained and described three new viral families isolated from amoebae: Mimiviridae, Marseillevirus and the virophage $[10,11]$. Obtaining the genome of these viruses made it possible to test for them in metagenomic databanks, and we discovered that these viruses are almost ubiquitous and found in the majority of unfiltered databank samples $[11,12]$.

We have therefore devoted this special issue of Intervirology to Mimivirus, the giant virus of amoebae. The articles presented in this issue cover various aspects of Mimivirus and other giant viruses of amoebae. Thomas and Greub discuss the role of amoebae in relation to bac- 
terial symbionts [13]. Desnues and Raoult describe the cycle of the virophage and the rationale for its name [14]. Raoult and Boyer report on the role of amoebae as genitors of new microorganisms [4]. La Scola et al. describe the preliminary identification by MALDI-TOF of new giant viruses of amoebae isolated from fresh water, sea water and the ground [15]. The genomic analysis of Mimivirus and other large viruses is explored in more detail by Colson and Raoult [16]. ORFans in giant viruses are discussed by Boyer et al. [17], and the evolution of eukaryotic large nucleo-cytoplasmic DNA viruses is addressed by Koonin and Yutin [18]. The exchange of genes is studied in particular by Filée and Chandler [19], and the implications of giant viruses on the definition of viruses is discussed by Forterre [20]. Klose et al. share the latest images obtained by the three-dimensional study of Mimivirus [21]. Lastly, the potential pathogenicity of Mimivirus in relation to macrophages is studied by Ghigo [22] at the cellular level, and Vincent et al. report the results of various experimental and clinical studies that investigate the pathogenic role of Mimivirus [23].

On the whole, Mimivirus and the giant viruses of amoebae have opened a new page of virology and have incited an intense debate regarding the very definition of viruses [1,24, 25]; some of these debates are particularly impassioned because they center on fundamental questions of the definition of life. These include very basic queries, such as: What is life? Are viruses alive? Are viruses organisms? These questions are seemingly more religious or semantic than scientific. Ultimately, the current definitions should accommodate our current knowledge of all viruses, including the giant viruses (see Box 1).

The definition of life is a matter of semantics, not necessarily of science; however, to some, it may be considered as the ability to transfer information encoded by genetic material. Genetic storage systems include viruses, which use a capsid as a vehicle, as well as cells. Only cells can process information, since they possess ribosomes, thus allowing transduction of information. Cells and virus are mosaics of genes from different origins and should be defined both physically (as particles) and genetically by their essential genes (i.e. ribosomes for cells and capsids for virus). Other genetic elements are selfish parasites. Organelles are not cells, since their complete genome is not held within the particle. Herein, we redefine living objects according to their level of independence.

The definition of an organism is a difficult problem in itself and is subject to controversy. An organism has been defined as 'An individual living system such as animal, plant, fungus or microorganisms' by Wikipedia, 'An in-
Box 1. Defining living entities

- Define life as 'a condition that distinguishes organisms from inorganic objects'. The frequently used 'reproduction' criterion does not apply to sterile organisms (e.g. mule, bees, ants).

- Life is a characteristic of self-organizing, self-recycling systems consisting of populations of replicators that are capable of mutation around which homeostatic, metabolizing organisms evolve.

I propose the following definitions:

- A cell is a physically observed object containing a genome encoding for ribosomes. It may be classified using $16 \mathrm{~S}$ and $18 \mathrm{~S}$ ribosomal DNA sequences in Eukarya, Bacteria or Archae. For Eukarya, it is classified according to the sequence of the nucleus, excluding organelle sequences. A cell cannot be defined (as it is common now for Bacteria) exclusively based on sequences. It is not only an association of genes.

- A virus is a parasite particle defined by the presence of a capsid and genetic material, including capsid-encoding genes (excluding viroid plasmids and some satellites); they are classified according to their host as: Eukarya viruses, bacteriophages, Archae viruses or virophages.

- Genetic elements are selfish, motile, free nucleic acids using viruses or cells as stores and/or are replicated; this includes satellite nucleic acids, transposons, plasmids and retroposons. Integrated former retroviruses are considered to be more independent genetic elements.

dividual animal, plant or single-celled life form' by the Oxford English Dictionary Online and 'Any living structure capable of growth and reproduction' by Chambers Reference Online [1]. The definitions from Wikipedia and the Oxford English Dictionary Online exclude intracellular parasites, symbionts, organelles and viruses. The definition from Chambers Reference Online, however, includes viruses and nucleic acids.

I hope that this series of articles devoted to this entirely new field will fuel the debate on viruses and their place in the living world. In this respect, it is interesting that post-modern philosophers Deleuze and Guattari [26] proposed the name 'rhizome' to re-qualify human and social organizations [26]; I re-used this term myself to qualify the complexity of the origin of genes in living organisms [27]. In their book, Deleuze and Guattari explained the non-vertical transfer of information, using the work of Jacob on bacteriophages, and used viruses as a paradigm to explain the absence of linearity in the transmission; this is in opposition to the ideas of the 18th 
and 19th centuries, which included the ideas of Darwin. Personally, I believe that viruses are part of the all-living world and therefore of the rhizome of life [27].

Finally, most of the viral dogmas were based on filtration as a basic definition. As I am not a virologist to start with, but rather a rickettsiologist (studying Rickettsia species, which are intracellular bacteria), I did not devel- op the taboos present most commonly in the field of virology. As a consequence, I do not see major differences in the morphological, genomic, proteomic and transcriptomic data between giant viruses and small intracellular bacteria [28]. I believe that this radically different approach and new perspective will help to reshape the virus world.

\section{References}

$\checkmark 1$ Raoult D, Forterre P: Redefining viruses: lessons from Mimivirus. Nat Rev Microbiol 2008;6:315-319.

-2 Edwards RA, Rohwer F: Viral metagenomics. Nat Rev Microbiol 2005;3:504-510.

$\checkmark 3$ Merhej V, Royer-Carenzi M, Pontarotti P, Raoult D: Massive comparative genomic analysis reveals convergent evolution of specialized bacteria. Biol Direct 2009;4:13.

4 Raoult D, Boyer M: Amoebae as genitors and reservoirs of giant viruses. Intervirology 2010;53:75-83.

5 Greub G, Raoult D: Microorganism resistant to free-living amoebae. Clin Microbiol Rev 2004; 17:413-433.

$\checkmark 6$ Raoult D, La Scola B, Birtles R: The discovery and characterization of Mimivirus, the largest known virus and putative pneumonia agent. Clin Infect Dis 2007;45:95-102.

La Scola B, Raoult D: Afipia felis in hospital water supply in association with free-living amoebae. Lancet 1999;353:1330.

$>8$ La Scola B, Raoult D: Survival of Coxiella burnetii within free-living amoebae Acanthamoeba castellanii. Clin Microbiol Infect 2001;7:75-79.

9 La Scola B, Audic S, Robert C, Jungang L, de Lamballerie X, Drancourt M, Birtles R, Claverie JM, Raoult $\mathrm{D}$ : A giant virus in amoebae Science 2003;299:2033.

10 La Scola B, Desnues C, Pagnier I, Robert C, Barrassi L, Fournous G, Merchat M, SuzanMonti M, Forterre P, Koonin E, Raoult D: The virophage as a unique parasite of the giant Mimivirus. Nature 2008;455:100-104.
1 Boyer M, Yutin N, Pagnier I, Barrassi L, Fournous G, Espinosa L, Robert C, Azza S, Sun S, Rossmann MG, Suzan-Monti M, La Scola B, Koonin EV, Raoult D: Giant Marseillevirus highlights the role of amoebae as a melting pot in emergence of chimeric microorganisms. Proc Natl Acad Sci USA 2009; 106:21848-21853.

$\checkmark 12$ Raoult D, Audic S, Robert C, Abergel C, Renesto P, Ogata H, La Scola B, Suzan M, Claverie JM: The 1.2-megabase genome sequence of Mimivirus. Science 2004;306: 1344-1350.

13 Thomas V, Greub G: Amoeba/amoebal symbiont genetic transfers: lessons from giant virus neighbours. Intervirology 2010;53:8-21.

14 Desnues C, Raoult D: Inside the lifestyle of the virophage. Intervirology 2010;53:47-57.

15 La Scola B, Campocasso A, N'Dong R, Fournous G, Barrassi L, Flaudrops C, Raoult D: Tentative characterization of new environmental giant viruses by MALDI-TOF massspectrometry. Intervirology 2010;53:98-107.

16 Colson P, Raoult D: Gene repertoire of amoeba-associated giant viruses. Intervirology 2010;53:84-97.

17 Boyer M, Gimenez G, Suzan-Monti M, Raoult D: Classification and determination of possible origins of ORFans through analysis of large nucleocytoplasmic DNA viruses. Intervirology 2010;53:64-74.
18 Koonin EV, Yutin N: Origin and evolution of eukaryotic large nucleo-cytoplasmic DNA viruses. Intervirology 2010;53:38-46.

19 Filée J, Chandler M: Gene exchange and the origin of giant viruses. Intervirology 2010; 53:108-115.

20 Forterre P: Giant viruses: conflicts in revisiting the virus concept Intervirology 2010; 53:116-132.

21 Klose T, Kuznetsov YG, Xiao C, Sun S, McPherson A, Rossmann MG: The three dimensional structure of Mimivirus. Intervirology 2010;53:22-27.

22 Ghigo E: A dilemma for viruses and giant viruses: which endocytic pathway to use to enter cells? Intervirology 2010;53:28-37.

23 Vincent A, La Scola B, Papazian L: Advances in Mimivirus pathogenicity. Intervirology 2010;53:58-63.

24 Moreira D, Lopez-Garcia P: Ten reasons to exclude viruses from the tree of life. Nat Rev Microbiol 2009;7:306-311.

25 Krupovic M, Bamford DH: Does the evolution of viral polymerases reflect the origin and evolution of viruses? Nat Rev Microbiol 2009;7:250.

26 Deleuze G, Guattari F: Rhizome: introduction. Paris, Éditions de minuit, 1976.

27 Raoult D: The post-Darwinist rhizome of life. Lancet 2010;375:104-105.

28 Raoult D: There is no such thing as a tree of life (and of course viruses are out!). Nat Rev Microbiol 2009;7:615. 